\title{
Neonatal adrenoleukodystrophy
}

INSERM

\section{Source}

INSERM. (1999). Orphanet: an online rare disease and orphan drug data base. Neonatal adrenoleukodystrophy. ORPHA:44

Neonatal adrenoleukodystrophy (NALD) is the variant of intermediate severity of the PBD-Zellweger syndrome spectrum (PBD-ZSS; see this term), charcterized by hypotonia, leukodystrophy, and vision and sensorineural hearing deficiencies. Phenotypic overlap is seen between NALD and infantile Refsum disease (IRD) (see this term). 